\title{
Post-politics contested:
}

\section{why multiple voices on climate change do not equal politicisation}

\author{
Anneleen Kenis ${ }^{*}$ \\ Research Foundation - Flanders (FWO), Division of Geography and Tourism, KU Leuven, Belgium \\ Department of Geography, King's College London, UK \\ *Email: Anneleen.kenis@kuleuven.be or Anneleen.Kenis@kcl.ac.uk
}

This is the accepted version of an article published in Environment and Planning C: Politics and Space. Check the following website for the final, published version: https://doi.org/10.1177/0263774X18807209.

To cite this article: Kenis, A. (2019). Post-politics contested: why multiple voices on climate change do not equal politicisation. Environment and Planning C: Politics and Space, 37 (5) 831-848. DOI: 10.1177/0263774X18807209 


\title{
Post-politics contested:
}

\section{why multiple voices on climate change do not equal politicisation}

\begin{abstract}
Contemporary discourses on climate change have been analysed as profoundly depoliticised. At the same time, this post-political thesis has been challenged for not taking the multiplicity of voices and actually existing forms of contestation into account. In this paper, I investigate the tension between these two positions and show that the existence of diverging voices and environmental struggles does not disprove the post-political thesis as such. I do this both from a theoretical and an empirical point of view. Theoretically, the paper presents a rereading of post-foundational theory and its implications for dealing with climate change. Empirically, the paper is based on activist research in the Transition Towns and Climate Justice Action movements, which have variably been depicted as profoundly political and depoliticised. The paper argues that it is often overlooked that it is on the level of discourse or representation that the diagnosis of post-politics should be made. It is not reality as such which is post-political, but the way reality is portrayed and thereby constructed. On this basis I argue that post-politics is a real problem for grassroots climate movements and that the attempt to overcome it is not only a necessity but also a profound challenge for them.
\end{abstract}

Key words: post-politics, climate change, convergence spaces, social movements, politicisation, democracy, Transition Towns, Climate Justice Action, green economy

\section{Introduction}

\subsection{Contesting post-politics}

In his book Climate Change and Society, Urry (2011: 90) calls the diagnosis that our current era would be post-political a 'new orthodoxy', thereby going against an expanding stream of literature arguing that predominant discourses on climate change are profoundly depoliticised (Bettini 2013; Goeminne 2012; Kenis and Lievens, 2014; MacGregor 2014; Machin 2013; Maeseele 2015; Pepermans and Maeseele 2016; Swyngedouw 2007; 2010; 2013). In contrast to this 'post-political thesis', Urry (2011: 91) argues there actually exists a broad range of different types of climate politics, 'and it is odd to write them all off as only "post-political"'. He particularly targets Swyngedouw's work, stating that Swyngedouw strangely 'seems unaware' of the emerging 'kinds of environmental movement, protest and discourse, including direct protest such as climate camps'. As an example, Urry (2011: 92) points to the case of the Transition Towns movement, which he considers as 'significantly political since it challenges the sedimented systems of twentieth-century carbon capitalism'.

Urry's argument is shared, albeit with many nuances, by a number of other scholars of recent grassroots climate movements, in particular North (2010), Featherstone (2013), Chatterton and Routledge (2013). They all somehow question the post-political thesis and they refer to new grassroots climate movements such as Climate Justice Action and Transition Towns to substantiate their claims.

Featherstone (2013: 46), for instance, considers the emergence of the Climate Justice Action movement a clear sign that it is too easy to diagnose current climate change discourses as generally depoliticised: 
There are [...] important tensions in this argument. In common with other work which adopts a post-political turn, it develops a rather limited engagement with the forms of contestation that are being shaped in the current conjuncture. While there are key attempts to de-politicise key issues such as climate change, to argue that these are the only ways that such politics is being articulated is reductive.

North (2010: 592), in his turn, rejects the post-political thesis by referring to the case of Transition Towns:

This paper critiques Swyngedouw's conceptionalisation of the politics of climate change as inevitably reducible to 'post-political' conceptions of sustainability, arguing that climate change and resource crises, including peak oil, are contested over the extent that these crises provide the opportunity to move away from an integrated global economy.

All these authors rightly point to the fact that a multiplicity of climate discourses exist, and that grassroots movements such as Transition Towns and Climate Justice Action are consciously going against the stream, trying to develop counterhegemonic discourses. However, is this enough to conclude that these movements are 'political', that climate change is therefore a politicised terrain and that the post-political thesis is wrong? This paper will address these questions and defend the post-politics thesis, both theoretically and empirically.

\subsection{Convergence spaces}

Interestingly, in some of these approaches, movements such as Transition Towns and Climate Justice Action are merged together in one category of 'new grassroots climate movements' which question dominant discourses, and would thus politicise climate change. Drawing on Routledge (2003), North (2011: 1583) makes this idea explicit by describing these movements as being part of the same 'convergence spaces', which he defines as spaces 'within which organisations, networks and activists act independently, coalesce, act together, then disperse again'. ${ }^{1}$ According to him, movements such as Transition Towns and Climate Justice Action share a common analysis of the problem, but in their attempt to tackle it, they choose different strategies. As he argues, ' $f$ ] $]$ or activists, no one scale or technique [...] is privileged. [...] The different tendencies and networks that organise in this space do not do so in competition with each other, but in complementary ways'. The idea is that different forms of engagement can be fully complementary in that they all somehow work together towards a larger goal. The broad '(grassroots) climate movement' is thus represented as a terrain of complementarity and mutual reinforcement.

As such, this can be an attractive position: individuals do not have to ponder too much on how to give shape to their ecological commitment, but they can swiftly switch from one approach to the

\footnotetext{
${ }^{1}$ It has to be noted that North (2011) slightly adapts the meaning that Routledge originally gave to this concept. Importantly, Routledge (2003) develops the concept of convergence spaces in the wake of the alterglobalisation movement. Drawing on Naomi Klein's (2002) observation that the demonstrations at the time 'represent the convergence of many different movements each with different goals and targets, but with a shared common cause: to resist the neoliberal agenda' (Routlegde 2003: 336), Routledge underlines that activists within these convergence spaces share 'common concerns', 'articulate collective visions', and 'generate sufficient common ground to generate a politics of solidarity' (Routlegde 2003: 345). North, on the other hand, uses the term to describe the contemporary field of climate politics, failing to acknowledge that this is an entirely different, much less politicised terrain of struggle. Undoubtedly, this diverging context also influences the meaning of the term. In this article, I will therefore criticise the validity of this term to describe current climate politics. More precisely, I will question that new grassroots climate movements like Transition Towns and Climate Justice Action can be conceived as being part of the same convergence spaces.
} 
other, as all are reinforcing each other. Movements should not compete with each other for hegemony within the broader camp of political forces combating climate change.

However, the question is whether it is really that simple? Do different climate movements really contribute to realising the same goal? And how do these movements' participants experience this concretely?

\subsection{Polemics}

In this paper, I present the results of a study on processes of politicisation and depoliticisation in recent grassroots climate movements, more in particular Transition Towns and Climate Justice Action. As I argue, there is something of great 'political' importance at stake in the choice between an engagement in one or the other of these two movements. Empirical research did not only show that the discourses of both movements widely diverge on a more fundamental level, but also that the representation of their mutual relations in terms of convergence spaces is not innocent. Challenging this idea of convergence spaces, I will show that post-politics is a real problem for grassroots climate movements and that the attempt to overcome it is not only a necessity but also a profound challenge for them.

Interestingly, the two movements under study have been at the centre of a scholarly debate concerning post-politics and climate change. Whereas Climate Justice Action is mostly seen as politicising, Transition Towns has variously been depicted as profoundly political and depoliticised (Chatterton et al., 2013; Featherstone, 2013; Mason and Whitehead, 2012; Neal, 2013; North, 2010, 2011; Urry, 2011). A crucial question is therefore what is the ground of these divergent diagnoses, and what this tells us about the state of 'the political', and its theorisation, today.

A steadily growing number of scholars has questioned the 'post-political thesis' for not taking the actually existing multiplicity of voices and forms of contestation enough into account (Chatterton et al., 2013; Featherstone, 2013; Larner, 2014; McCarthy, 2013; North, 2010; Urry, 2011). Not only do they argue that several climate movements are opposing the current post-political atmosphere, the concept of post-politics is increasingly contested itself. As I will argue in what follows, the paradox, in my view, is that in the contestation of the concept of post-politics in the environmental field, recourse is often made to post-political representations of that very field. The research conducted in the Transition Towns and Climate Justice Action movement contributes to assessing this paradox and the related scholarly positions.

In order to make this argument, the paper is structured as follows: in the next section, I present a short overview of the post-foundational political theories which form the philosophical background of the current debate. Subsequently, I present the research design, and discuss the main findings. Starting with a comparison of the discursive nodal points of both movements, I argue these nodal points exhibit substantial differences, while they at the same time share a key formal feature. In both cases, a mean-ends reversal seems to be taking place, as both movements seem to use climate change to a certain extent to promote a broader interest or aim. This common formal feature does not refute the divergence observed on the substantial level. It rather shows that under the surface, a more important hegemonic struggle is taking place. Crucial is the question how both movements make sense of this 'struggle in disguise', or, more precisely, which place they attribute to 'the political'. Indeed, as I show, even more than the differences in nodal points, what differentiates both movements is the extent to which they politicise their own stakes and goals. In a next step, I underline the paradoxical effect of the focus on 'the political': if the debate gets centred around the issue of 'the political', what really matters, namely the content of the debate, risks to be lost out of sight. This insight will lead me 
to an answer on the question of convergence spaces, and consequently on the question of climate change and post-politics.

\section{Theorising the political}

Post-foundational political theory, has been principally developed by political theorists such as Mouffe (2000; 2002; 2006), Laclau (1996), Žižek (2000) and Rancière (2001; 2006) and has been introduced into the field of environmental/geographical studies by scholars such as Dikeç $(2005 ; 2012)$, Swyngedouw (2007; 2010; 2013), Featherstone and Korf (2012), Meyer et al. (2012) and Machin (2013). As the relevance of the concept of post-politics has increasingly been questioned within this field (Chatterton, et al. 2013; Featherstone 2013; Larner 2014; McCarthy 2013; North 2010; Urry 2011), it is important to delineate it as precisely as possible.

First, it is important to heed a distinction between 'politics' and 'the political' (Marchart 2007; Mouffe 2006; Rancière 2001; 2006; Žižek 2000). While the debate about the meaning of the (post)political is quite sophisticated and complex, and different scholars define these notions differently, for many of them, 'politics' refers to the sphere of the institutions such as the parliament or voting. 'The political', in contrast, refers to an order of discourse, a kind of logic of acting and thinking, which recognises the reality of power, dissensus and decision and which gives a place to conflict and debate on different ways to conceive of current and future society. Consequently, a discourse can be said to be post-political when it (1) misrecognises the constructed and therefore contingent nature of the social, (2) conceals that each such construction entails certain exclusions and therefore generates conflicts or antagonisms, and (3) obfuscates that the construction of the social inevitably entails acts of power (Kenis and Lievens, 2014). In other words, the discursive concealment of contingency, conflict and power is constitutive of post-politics (Laclau and Mouffe 2001; Mouffe 2006; Rancière 2001; 2006; Žižek 2000).

Second, and related to this, it is important to notice that a focus on discourse (or in the case of Rancière, a focus on the order of the sensible) is the red thread running through the different conceptualisations of the political. Indeed, it is on the level of ideas or representations (discourses) that 'the political' is affirmed or concealed. In other words, while all social relations are discursively constructed, and while this always entails the exercise of power, specific discourses can remain blind to their own political dimension or can even actively conceal it. It is at this moment that we call specific discourses depoliticised or post-political. A politicised discourse, in contrast, is one which recognises fully that it is political.

To understand precisely what is at stake, it is useful to take recourse to the work of Mouffe. As Mouffe $(2002 ; 2006)$ argues, each discursive constitution of the social generates certain exclusions, and these can become the inscription points for forms of antagonism. According to her, the political is fundamentally about recognising the constitutive reality of antagonism: whether one likes it or not, there will always be divisions, disagreements, distinctions between 'us' and 'them'. The key question is what form they will take. Mouffe argues that recognising these conflicts is crucial from a democratic point of view: only in this way antagonism can be turned into agonism, a relation between adversaries who fight each other while recognising the legitimacy of each other's position and respecting each other's right to defend it. In contrast to antagonists, agonists share a common symbolic framework centred around key principles such as equality and freedom, about whose central importance there is consensus, even if not about their specific meaning. Depoliticisation, on the other hand, occurs when 
the exercise of power and the antagonisms that result from it are covered up. As Mouffe argues this can lead to a situation in which the conflict gets worse and becomes even unmanageable, as it might degenerate into a fight between enemies, who cannot but try to destroy each other.

Rancière's $(2001 ; 2006)$ approach to politics seems quite different at first sight, although his fundamental intuitions are similar to Mouffe's. He distinguishes between 'politics' and 'police', arguing that political action is about making something visible that was previously invisible, or making certain unheard voices hearable. This stands in opposition to a managerial 'police' (or in my words 'postpolitical') logic which suggests there is nothing to be seen or heard beyond the status quo. The aim is to maintain what already exists. A political act, according to Rancière, always happens under the assumption of the equality of each and everyone. By acting as if one is equal to another, the normal (hierarchical) order of things is disturbed, and as a result, the inevitably inegalitarian police order appears as fundamentally contingent. This moment of subversion of the existing order is, according to him, the hallmark of political action.

This insight brings us to a third point. Although the theories of scholars like Mouffe and Rancière differ on several points, what they have in common is a specific position towards what Marchart (2007) calls 'society's foundation'. Crucially, what happens in depoliticised discourses is that society's contingency is rendered invisible by representing society as if it had an ultimate foundation. Such a representation of society takes away the symbolic conditions of possibility of conflict and contestation, which, as a result, are neutralised or thus depoliticised.

This is deeply problematic because, fourthly, democracy is at stake. Indeed, according to these authors, democracy is about maintaining an openness for society to be put into question. The central idea of democracy is that it requires a recognition and a making visible (and contestable) of the power that organises society and of the exclusions, and thus potential conflicts, this generates. In other words, a society is democratic when it recognises that it is contingent and lacks an ultimate foundation (Marchart 2007). Or, as Mouffe (2002: 33-34) argues: 'Instead of trying to erase the traces of power and exclusion, democratic politics requires us to bring them to the fore, to make them visible so that they can enter the terrain of contestation'.

As I will argue in what follows, critics of the post-political thesis turn these ideas upside-down: they suggest the theoretical focus on post-politics remains blind to actually existing forms of resistance and even makes resistance invisible. In my analysis, however, creating an openness for resistance is precisely what the critique of post-politics is all about.

\section{Research Design}

In order to deal with these topics in an empirically grounded way, I engaged in a qualitative embedded multiple case study of the rise of the Transition Towns and Climate Justice Action movement in Flanders (Belgium) (Esterberg 2002). The choice to focus specifically on these two movements did not follow from theoretical considerations, but resulted from the observation that they constituted the most important grassroots climate forces in Flanders at that time. In order to grasp the processes at stake, I combined the analysis of an extensive range of leaflets, booklets, books, press releases, websites and other materials with 40 semi-structured in-depth interviews (20 interviews with climate justice activists and 20 with transitioners) and a genuine engagement as an activist researcher in the field (Hale, 2008). The latter implied that for several years on end, I was an active participant amongst the other participants, taking part in meetings, activities and actions and doing my share of the 
practical tasks, while at the same time maintaining a position as a researcher. Through the combination of my experiences and observations as an activist researcher and the interviews and document analyses, I aimed to arrive at a thick and rich description of the discourses developed by these movements and their participants, of which I was also a part (Baxter and Eyles 1997)2.

For practical, ethical and epistemological reasons, I chose to use the information collected on the basis of activist involvement and document analysis mainly as general background knowledge, whereas the data obtained through the interviews provided the 'hard' data on which I focused most analytic attention. As several scholars have argued, conducting interviews is one of the most suitable methods to grasp how people make sense of their own engagement and to understand how discourses are reconstructed in this process (Valentine 2005). Furthermore, working with semi-structured interviews allowed to clearly separate the stricter research setting from a broader research activism setting. By meeting in another place, putting a tape recorder in between me and the participants, the participants were well aware of the research context and the fact that their words could be used as quotes in research papers. ${ }^{3}$ No quotes presented in this paper are therefore drawn from other situations than these semi-structured interviews.

In order to analyse the interviews in the most rigorous way, they were all fully transcribed, coded and analysed in detail with the help of the software program NVIVO ${ }^{\circledR}$. Crucially, during these interviews I did not only ask people about their own engagement, but also whether they could envisage to get engaged in the other movement. This information helped me to acquire an in-depth view of the similarities and differences between both movements. Interestingly, only a small minority of the interviewees said they could imagine to become involved in the 'other' movement. As I will show in what follows, the source of this division has not so much to be sought in 'substantial' differences, but in both movements' different attitude towards 'the political'.

\section{Research results and discussion}

\subsection{Nodal points}

Without any doubt, Transition Towns and Climate Justice Action have much in common: both are new grassroots climate movements that challenge conventional environmental approaches. Both can be said to be radical and innovative. However, despite these commonalities, my research shows that on a more fundamental level both movements differ strongly. To start with, their defining discourses are centred around entirely different 'discursive nodal points' (Howarth et al. 2000; Mouffe and Laclau 2001).

Transition Towns starts from the building of resilient local communities to ward off the dangers of climate change and peak oil (Brangwyn and Hopkins 2008; Hopkins 2008b). Positive, constructive and all-inclusive activities are seen as key to achieving this. Typical examples are community gardening, repair shops, herbal walks and cooperative solar energy production. As Bailey et al. (2010:598) argue: Transition Towns 'solutions are construed as intrinsically local, in the general sense of relocalisation and in a specific focus on community-scale action', and many participants agree with this. They do not

\footnotetext{
2 This is relevant in the sense that the critique I develop is a critique which I develop from within, being a dedicated member of both movements. For that reason it is by definition also a self-evaluation and selfcritique.

${ }^{3}$ This is especially of importance for activist researchers whose position as a researcher risks to be forgotten through years of common activity and engagement.
} 
only point to the enormous spill of oil and the related $\mathrm{CO}_{2}$ emissions resulting from our globalised economic system, but also to the fact that this system makes people vulnerable for significant crises. As transitioner Anna explains, with our globalised model we are 'only three days away from famine' if a serious crisis would happen, because we completely depend on super markets for food: 'if the shelves are empty, we have a big problem'. She concludes: 'if you are more independent you have evidently less problems if these crises come ahead'. ${ }^{4}$

Importantly, however, 'localisation' and 'community-building' are more than mere strategies to deal with peak oil and climate change: they have an intrinsic importance (Mason and Whitehead 2012; Neal 2013; North 2010). As Anna notices: 'living in a local and connected way, that is the core of Transition Towns for me [...] We have to move away from globalisation. [Because] that isn't our dimension. We have to look at what is ...uh ... the right scale'. Similarly, Ronny underscores: 'the relocalisation of social life is most important for me.' Several other transitioners also underline that the communal and local aspect of the movement is what attracts them most. It is almost as if they have been waiting for yet another reason to put localisation and community building on the public agenda (again) (Kenis, 2016; Kenis and Mathijs, 2014a).

Therefore, describing Transition Towns as a grassroots climate and peak oil movement insufficiently captures its essence. The movement seems to be in first instance about localisation and community building, whereby it refers to climate change and peak oil to underpin its project and claims. For example, Transition Towns protagonists point to the fact that '[n]ew resource discoveries, technological breakthroughs, market swings and economic cycles all have the potential to alter public sentiments towards relocalisation' (Bailey, et al. 2010: 603). They emphasise that in order to make sure that localisation remains 'salient' despite these changing circumstances,' $[d]$ ifferent elements of the message will [....] need to be stressed at different times'. In other words, other arguments can also be used in view of supporting localisation and community formation, when necessary.

Climate Justice Action, on the other hand, seems to be structured around entirely different nodal points. As an internationally oriented movement which especially gains momentum during the climate summits of the UNFCCC, its focus is on challenging the 'false solutions' of the 'Green Economy' (e.g., emissions trading, agrofuels, carbon capture and storage, GMOs and nuclear energy) and on advocating 'climate justice' instead (Featherstone 2013; Kenis, 2016; Kenis and Mathijs, 2014b). Through the construction of climate justice as the unifying signifier, Climate Justice Action explicitly aims at bringing together a range of movements and individuals within a broad alliance connecting climate politics with the question of social justice. Several climate justice activists even state that more than the issue of climate change as such, the reframing of the climate struggle in justice terms is what attracts them to the movement. As Gregory explains: 'the movement we want to build is not strictly a climate movement, but a kind of synthesis of very different questions and backgrounds, which puts forward a more universal perspective. Climate and justice, taking the future in our hands, that has much more emancipatory perspective than the environmental aspect in a strict sense.' Having been part of previous movements, such as the global justice movement, and inspired by the writings of movement's intellectuals such as Müller (2008), several of them consider climate justice as an opportunity to rebuild or revitalise previous cycles of struggle. As Kenneth states: 'for me, climate change is perhaps also a bit a pretext to engage in more important things [...] such as the differences

\footnotetext{
${ }^{4}$ All first names used in this paper refer to transitioners or climate justice activists I interviewed. They have been modified for reasons of anonymity.
} 
between North and South, our way of living, etc. [...] The idea is simply that things have to start moving and that we can realise system change.'

'System change, not climate change' being its central slogan, 'system change' could be seen as the second nodal point of the movement's discourse. As with the nodal point of climate justice, it is constructed in such a way as to facilitate a large convergence of different movements against the 'system', usually understood as capitalism. As Alice states, 'it is very simple: the world turns on a system that is based on the exploitation of people and planet'. She considers this as the basis of most contemporary problems, including climate change. Importantly, Climate Justice Action posits that this system is not only a root cause of climate change, but also a main obstacle impeding adequate solutions from being implemented (CJA-Leaflet 2009; ClimateCollective 2009). In order to arrive at 'real solutions', Climate Justice Action advocates 'direct action' instead. This can be identified as a third nodal point. Its purport is both strategic, referring to the type of action needed to ward off climate change, and democratic, implying a specific vision of bottom-up participation in realising social change (Kenis and Mathijs, 2014b).

\subsection{Reversals}

As becomes clear in these examples, despite huge substantial differences, the discourses of both movements have one peculiar formal feature in common. Indeed, they both undertake a similar discursive operation. In both cases a means-ends reversal seems to be taking place. Neither for Transition Towns, nor for Climate Justice Action, tackling climate change appears to be the main or final objective. Both movements use, to a certain extent, the language of climate change to frame their more fundamental concerns and societal projects: localisation and a revitalised community life in the case of Transition Towns, and social justice and system change in the case of Climate Justice Action. This is not to suggest that climate change as such would not be important and even essential for both movements (and especially for many of their participants). But their real focus appears to lie elsewhere.

As I already showed, for many climate justice activists climate change is a red thread that enables them to connect a series of social and ecological concerns, integrate these into one overarching story, and put them on the agenda (again). In the words of Alexis: 'The interesting thing is that all elements which require political action are united in the overarching denominator of climate change. Because basically it is about system critique. And the system manifests itself in several ways. Climate is one of them, and everything else can be subsumed under it.' In other words, Climate Justice Action not only, or especially, wants to realise system change and justice in order to tackle climate change, but also uses the language of climate change as a starting point to advocate social justice and system change. Its focus on climate change seems to serve its fight against the capitalist economy and its perverse effects.

Interestingly, in a way, Climate Justice Action thus enacts a move that is somehow similar to the typical argument of its strongest opponent, the project of the Green Economy, the emerging policy framework which has become increasingly hegemonic amongst international institutions, environmental lobby groups and a number of corporations (OECD 2011; UNEP 2011). The Green Economy project supports market mechanisms in order to tackle climate change, arguing that this will not only help realising a sustainability transition, but will also create plenty of economic opportunities. This amounts to a peculiar means-ends reversal whereby tackling climate change is presented as the 
royal road to overcoming the problems and crises of the market (Kenis and Lievens, 2015; 2016). To the extent Climate Justice Action refers to climate change as a way to promote system change and climate justice, it does something similar, albeit with the opposite goal: climate change becomes the starting point for putting the anti-capitalist struggle on the agenda again. Significantly, Transition Towns also operates such a reversal: the building of vibrant local communities seems to be its main project, while peak oil and climate change often appear to especially provide a frame which allows the movement to advocate localisation and community building, or to underpin the discourses which have to justify this advocacy. Under the surface, a more important hegemonic struggle thus seems to be taking place. This struggle is not only, or in the first place, about which strategies are most appropriate to ward off climate change, but about divergent societal projects, which are re-framed in terms of climate change in order to give these projects a new boost and credibility. In other words, the choice for the Green Economy, for Climate Justice Action or Transition Towns is a choice for a specific societal project. Each of these projects amounts to a re-invention of previously existing projects, which are now reconfigured in the light of climate change.

\subsection{Hegemony in disguise}

Although they all realise a formally similar means-ends reversal, the discourses through which these initiatives make sense of their own activity strongly differ. While the Green Economy uses an economic, technocratic and managerial, and thus often profoundly depoliticised narrative (Kenis and Lievens, 2015; 2016), Climate Justice Action, on the other hand, strongly politicises, and sometimes even tends to over-politicise, in the sense that it frames the whole field of environmental struggle in terms of adversaries and allies, friends and enemies (Kenis and Mathijs, 2014b). While the Green Economy tends to conceal its political stakes, thereby complicating a debate about its proper aims, Climate Justice Action risks to go so far in its conflict approach that a proper debate, for instance with advocates of the Green Economy, is also not possible anymore. To the extent that the latter tend to be considered as enemies rather than adversaries (Mouffe 2006), they become actors that merely have to be defeated (instead of also convinced). The following quote of Jason is telling in this regard. Reflecting on how the movement should relate to 'green companies' he states:

So if that company is green, not out of environmental reasons but because it allows them to make money, but the same logic of profit is still present, workers are still exploited, the same capitalist practices are continued [...] Whether you call it an enemy or an opponent, I cannot see it as an ally. In no possible way, and especially because, somehow, I find this a worse category, a worse opponent because you see that in the end, they create a kind of confusion. Because some people say: look, now these activists are also against green companies. They thus make it more difficult for us.

Similarly, Tina underlines it is not worth the effort to engage with green companies because 'their biggest concern is not the climate or nature, but simply making profit. They are happy that this connects with consumers but... that it is better for the environment, that is not their principal concern.'

However, climate justice activists not only politicise strongly in relation to 'green' companies, but also towards other forces in the environmental movement, and even internally. With campaigns against well-known environmental charities like the World Wide Fund (WWF), they make very explicit how the camps have to be delineated according to them. While being evident from their political perspective, these kinds of campaigns seem difficult to understand for green activists who are less 
familiar with combative environmental struggles, alienating them rather than getting them closer to the climate justice cause.

But most importantly, the risk of over-politicisation refers to the tendency to politicise every single political difference within the movement (Kenis and Mathijs, 2014b). Though interesting from a political point of view, this tendency makes it by times difficult to keep the movement together. As Mouffe $(2000,2006)$ argues, politicisation requires the construction of an 'us' and a 'them'. As she puts it straightforwardly: 'there is no "us" without a "them"' (Mouffe, 2000: 12). However, paradoxically, when the focus is too much on constructing 'them', the very possibility of building an 'us' can be undermined.

Transition Towns provides the most ambiguous picture in relation to the political. With its plea for fargoing relocalisation the movement puts forward a radically different future alternative. By thus revealing, at least implicitly, the contingency of current societal structures, the movement in principle could contribute to the politicisation of the climate debate. Yet, remarkably, it does not seem to recognise the potentially political dimension of its own radicalness. On the contrary, while being radical in what it proposes, the movement wants to establish itself as much as possible as 'normal', 'familiar' and 'something for everyone', to quote some of my interviewees. The promotion of dialogue, all-round collaboration and inclusion is characteristic of the 'cosy' consensus atmosphere the movement wants to build. Conflict approaches are dismissed, every us/them discourse is rejected, and the psychology of change is put forward as the way to get it all done (Brangwyn and Hopkins 2008; Hopkins 2008b). In the words of Jessica: 'it's a positive story, right. It is not "anti". I think that is important. That people prefer to hear such a thing.' Similarly, Jacob stresses: 'What is nice about Transition is that it is like "come, let us show what we can do together". Well, not pointing your finger around [...] and thinking in dualities of "us-them".' Exactly because of the rejection of every 'us against them' discourse, the movement's narrative can be said to be fundamentally depoliticised, albeit in an entirely different way than is the case with the discourse of the Green Economy. Strikingly, post-political tendencies thus not only seem to be present in hegemonic climate discourses, but also in counterhegemonic ones.

The point is that Transition Towns' dismissal of conflict discourses, its call for far-going inclusion and the promotion of a psychological vision of change make a proper political debate between them and, for instance, climate justice activists, or proponents of the Green Economy, difficult, if not impossible. Indeed, the conditio sine qua non of a proper political debate is exactly the recognition of the reality of conflict, the inevitable presence of multiple divisions between 'us' and 'them', and the willingness to engage in a debate in these terms (Mouffe 2000; 2006). When engaging in conflict is represented in psychological terms, the conflict risks to get stranded from the beginning. The opponent is then not merely seen as having a different opinion. Her opposition is considered the symptom of psychological defences she sets up in order not to have to transcend or question her own assumptions and habits. The reproach is that she rather starts to blame others, or to vindicate the correctness of her own views, failing to open herself for other perspectives (see Mouffe (2006) for a similar argument with regard to moralistic discourses). It is in this way that we have to understand, and question, the idea expressed by many transitioners that 'it is much easier for many people to point to culprits' than to look to themselves, to quote Sophie. Transitioners argue that movements which organise on such a basis would be more successful and sometimes feel a bit resentful, or at least frustrated, about that. For themselves, transitioners put the 'challenge to really look to their own responsibility'. As Marc stresses, 'it is not fair to demand that someone else acts differently and to continue as previously yourself. Here, I am really supported to look at myself, and realise the change 
myself.' And he continues: 'It is crucial not to shift all responsibility to others. It is also about an internal transition, a transition in ourselves.'

\subsection{Against (being against)}

In my view, this difference in how both movements deal with 'the political' is fundamental. More than the different nodal points structuring their respective discourses, and even more than the concealing effects of the means-end reversals mentioned above, this divergent relation to the political seems to establish a real cleavage or chasm between both movements, making it difficult, if not impossible, for them to engage in a real debate.

Interestingly, many transitioners would definitely argue in favour of climate justice and system change (though probably giving a slightly different meaning to these notions), and quite some climate justice activists are not against localisation, let alone community building, as such. However, the latter's dissatisfaction about Transition Towns' unwillingness to engage in more confrontational actions and debates, the social pressure to be always 'constructive' and 'positive' and to deal with each other in an almost psychotherapeutic way, made several activists flee from Transition Towns or reject it strongly. Similar things happened on the opposite side as well. Several transitioners felt sympathy for Climate Justice Action's aims, such as community control over natural resources, food sovereignty, settling the North's ecological debt to the South, and a 'just transition' to a low-carbon economy. At the same time, they had more difficulties with the idea that these solutions would 'not come without a struggle'. While some transitioners undertook a genuine attempt to engage with the Climate Action Camps organised by the Climate Justice Action movement in Belgium, they soon withdrew. Discussions quickly arose around some more confrontational elements: the fact that the terrains of the camp were occupied illegally, that security teams were set up to protect the terrains from invasions by the police, that the camps had a radically political outlook, which made 'not everyone feel welcome', and that blockades and other direct actions were organised. But especially the conflictual discourse, which was present in its outreach texts on websites and leaflets, led to strong feelings of unease on the side of transitioners. Most notable was a meeting of Climate Justice Action where a transitioner joined for the first time. A political discussion on the outreach text was taking place. He intervened saying it was important to avoid 'us against them' discourses. Before he could even finalise his sentence all other participants started to wave their hands down, a sign showing they strongly disagreed. The transitioner was clearly very surprised and even shocked by the reaction, similar interventions within meetings of Transition Towns had always led to strong approval. He never came to meetings of Climate Justice Action again.

Strikingly, when I asked my interviewees about the other movement, almost all expressions of 'disagreement' related to these kinds of issues which pertain to the political. Transitioners consider Climate Justice Action too 'conflictual', 'negative', 'extreme', and imprisoned in an 'us-against-them' discourse. Climate justice activists denounce that Transition Towns denies the presence of power relations and inequalities and thus the necessity of struggle. As Jason cries out after reading an outreach text of Transition Towns: 'of course there are culprits! You can say that it is more about institutions than about people. It does not have to be about people, but the oppositions are there anyway. An 'us' and a 'them', in the last instance. And so there is social struggle.' He grumbles: 'That's the danger of transition: I think it can be a useful initiative as such, as it brings people together on a local level, it can empower people. That is all fine, but the idea that there are no culprits is very problematic in my view.' Jean-Francois is also reluctant when reading a leaflet of Transition Towns: 
"What do they want to say, with "inclusion"? "We're all one big family", or something like that? The point is that this is not true. You are my exploiter. He goes on: 'They argue that "one fundamental misunderstanding is the belief that change is something that we have to fight for." Eh, well, you see. I do believe that. That is very clear. I believe they are completely mistaken here.'

Interestingly, even the way the participants talked about the other movement revealed to a certain extent their own political stance. When I asked transitioners about the Climate Justice Action movement, they often engaged in a psychologising (and sometimes moralising) discourse, suggesting Climate Justice Action is something for young people, people who are new to the movement, or for people who have not reached Transition Towns' level of maturity yet. The difference between both movements is thus not understood politically, in terms of divergent projects, but as resulting from different degrees of psychological (or moral) development. This leads transitioners to a slightly paternalistic attitude towards Climate Justice Action: they want to relate sympathetically to them, as it is assumed climate justice activists will realise sooner or later that Transition Towns is right, and transitioners want to warmly welcome these activists to change their minds and join their movement when they are 'ready' for it.

In contrast to this psychologising, moralising and sometimes paternalistic attitude, Climate justice activists rather express straightforward indignation about Transition Towns' positions. If they disagree with a particular point of view, they are happy to get involved in polemic and sometimes offensive debates. They do not mince their words, and loudly and clearly declare for everybody that they find this or that point of view of Transition Towns 'really unbearable'. Their firm and open announcement of disagreement is, in its turn, interpreted by transitioners as a lack of openness to engage in a 'real dialogue' and 'transcend' personal or particular positions which after all just divide us.

Interestingly, the respectively depoliticised or (over-)politicised positions of transitioners and climate justice activists thus also determine the way their participants relate or react to the other movement. If one sees the other as psychologically or morally immature, or if one believes in the possibility to arrive at an all-inclusive consensus, there is a structural obstacle to acknowledging fundamental disagreements (Kenis and Lievens, 2014; 2015; Machin 2013; Mouffe 2006). To put it simply, within a depoliticised mind-set, it is very difficult for two actors to agree that they disagree. Climate Justice Action, on the other hand, recognises the existence of disagreement, but its participants sometimes seem to find it difficult to recognise proponents of other perspectives as legitimate others. This is particularly valid if these others are advocates of the Green Economy, but to a certain extent it is also the case in relation to transitioners. In Mouffe's (2006) words, antagonism then cannot be turned into agonism, and the other risks to become an enemy. The result is not only a specific difficulty to engage in a proper political debate. It can also open the door for adversarial actions in spaces which are no longer political in the proper meaning of the term. Think about actions which trespass the boundaries of the private sphere, whereby action is undertaken, for example, at the doorstep of a CEO's home, where her children and partner also live. Even though 'the personal is political', as feminists state, the politicisation of the personal sphere can lead to disrespecting the adversary and making the conflict very psychological or moral, thereby again missing what is of the essence of the political (Mouffe 2006).

\section{5. (Contesting) the political: a non-debate?}


To really understand what happens at the level of the political, one final step has to be made. As I argued elsewhere, even in depoliticised discourses a symptomatic form of conflict pops up again (Kenis and Lievens, 2014; see also Lievens 2010; 2013). This is relevant to understand Transition Towns' relation to the political. In so far as Transition Towns feels the need to state, time and again, that we should be positive and collaborative, that we should avoid 'us versus them', that we do not win anything with 'continued fracturing and antagonising' and that we should stop thinking that 'change is something that we have to fight for' (Hopkins 2008a), Transition Towns' discourse is actually very polemical and conflictual in itself. Paradoxically, even consensus-seeking discourses engage in a peculiar kind of conflict against more adversarial discourses.

The proper meaning of political discourses can only be fully understood if this underlying polemical dimension is disclosed. Without a subtle polemic against discourses which advocate conflict, a discourse calling for inclusion and consensus would be entirely redundant and outright meaningless. Therefore, one could state that, despite its claim to the opposite, Transition Towns' discourse is subtly very polemical. More precisely, it is polemising against conflict discourses such as those put forward by Climate Justice Action. Paradoxically, therefore, depoliticised discourses often do take sides in a conflict. This conflict is situated on a meta-level, but it is a conflict nevertheless (Lievens 2013; Kenis and Lievens, 2014).

Interestingly, it could be argued that Climate Justice Action makes a similar, though opposite move. Indeed, is a conflict discourse implicitly not always directed towards consensus too? In so far as you suppose that your opponent understands the point you are making, you start from the assumption that there is a kind of common understanding underlying the different arguments. This is a point Rancière (1998) stresses. He argues that underlying a command is always a fundamental equality. This insight leads to his paradoxical analysis of the political act, which at the same time affirms conflict and the possibility to discuss between equals. Interestingly, this analysis is not only relevant to understand Climate Justice Action's position, it also seems to be the point at which the movement is balancing unstably. While its activists engage from time to time in political debates with their adversaries, and thereby implicitly acknowledge that 'the other' (or at least the public) can understand their point of view, there is also a tendency to refrain from these debates exactly for this reason. The assumption is then that the common basis is too small, or even inexistent to make a genuine debate possible or meaningful. In Mouffe's $(2002 ; 2006)$ terms, this is the moment when the adversary turns again into an enemy. The point of the matter is that something must be shared for enemies to be turned into adversaries, for antagonism to be turned into agonism. In other words, both complete consensus and outright antagonism are detrimental to the political. The key question is therefore to what extent climate movements acknowledge both the inevitability of conflict and the need for a minimal consensus which makes reciprocal recognition of adversaries possible.

As a result, the polemic between both movements is a strange one: it is a polemic which is not in the first place about what is of substantial importance for both movements, the societal project which underpins their respective climate change discourses. Instead, the debate is one between a collaborative approach and a conflictual one, between being 'against', and being 'against being against', between an often depoliticised and sometimes over-politicised approach. In other words, it is a debate about the place of the political as such, as a result of which the content of the debate, what really matters, risks to disappear from the agenda (once again). To put it differently, the conflict between localisation and system change, between community building and direct action, between inclusive and 'just' approaches tend to disappear out of sight to the extent that the conflict about the political as such takes the upper hand. 


\subsection{Convergence spaces?}

My argument thus far has pointed to a number of obstacles for establishing convergence between Climate Justice Action and Transition Towns. It is not only the case that a number of elements stand in the way of a joining of forces, at the level of the political both movements seem to even counter or thwart each other's projects, as one discourse objectively functions so as to dislocate the other (Howarth et al. 2000; Laclau and Mouffe 2001). In other words, both movements' discourses are not neutral to each other. Therefore, it should not only be questioned whether they can be considered as part of the same convergence spaces. My questioning goes a step further: the way both movements frame or conceal the political is so different, that they can actually become each other's opponents.

Furthermore, the question concerns the effect of framing both movements as convergence spaces. As suggested in the introduction, this framing results in a paradox. Several scholars argue that there is no problem of post-politics in relation to climate change (Chatterton, et al. 2013; Featherstone 2013; Larner 2014; McCarthy 2013; North 2010; Urry 2011), but one can wonder whether talking in terms of convergence spaces is in itself not already a post-political representation of the environmental field. The point is that post-political discourses do not only portray social reality in neutralising terms, but also neutralise or depoliticise their own relation to social reality. Therefore, not only the idea of convergence spaces, but also the critique concerning the post-political thesis should be subjected to closer scrutiny.

Scholars such as Mouffe $(2002 ; 2006)$ and Žižek $(2000)$ argue that the social is inevitably and always torn by conflict, division and the exercise of power. The post-political thesis does not deny this: it rather focuses on the question whether or not the discourses through which the social is interpreted account for these realities and make them visible. That is what the political and depoliticisation are about. Therefore, the very existence of a multiplicity of voices and actually existing forms of contestation does not disprove the post-political thesis as such.

Furthermore, it is important to note that discourse does more than portraying social reality: it co-produces this reality (Laclau and Mouffe 2001; Mouffe 2006). Discourse or representation is therefore far from an innocent affair: without discourse, society could not possibly exist as something meaningful. In this sense, both political and post-political discourses have performative effects on society, on how it interprets itself, or how social actors understand their own place within it. Postpolitical discourses do not only conceal the political nature of society, but also remain blind to the inevitably political nature of their own relation to society, namely to the fact that they co-produce it. The point is that if one is convinced that Transition Towns and Climate Justice Action constitute convergence spaces, there is no longer a need to think this space in political terms: it is then no longer an arena where important choices have to be made. The problem with a post-political representation is thus that it conceals struggles which are present below the surface.

\section{Conclusion}

In his book Climate Change and Society, Urry (2011: 90) argues that 'if Swyngedouw were right in these claims about the forming of the post-political, this would be highly problematic for developing a positive and progressive response to the multiple risks of changing climates'. But is this really the case? Post-politics is indeed an obstacle for tackling climate change in an effective and democratic way. But it is not this diagnosis that is responsible for the situation. On the contrary, the diagnosis exactly allows 
us to grasp what is at stake and to provide us with the conceptual tools to move beyond it. Mouffe (2002: 5) famously argues that ' $(t)$ he political in its antagonistic dimension cannot be made to disappear simply by denying it, by wishing it away [...]'. I want to argue that the same is valid for the post-political. Instead of denying a certain reality, the art is to understand it, in order to change it.

This does not mean that the critiques of theories of the post-political are built on thin air. In a certain way, the concept of 'post-politics' has been the victim of its own success. It has been used so often and in such a diversity of contexts, that its precise meaning has got lost. A vulgarisation of the notion of 'post-politics' is the result, which is vulnerable to easy critique or even ridicule, as is manifest in some scholarship (Barnett 2013). It is important, therefore, to restore the precise meaning of the concept of the (post-)political.

Firstly, it needs to be underscored that only discourses can be called post-political. Post-politics is about a way to represent or interpret social reality. A discourse is post-political when it conceals power, exclusion or conflict, or more precisely, when it conceals the fact that a discourse is in itself an exercise of power, generating exclusions and intervening in a conflictual terrain. The critique of postpolitics is therefore a critique of discourses: it aims to reveal what a discourse conceals, namely the contingent and therefore changeable political nature of society and of a discourse's relation to it.

Secondly, the concept of post-politics is not a descriptive, but a critical term. It does not describe reality, but it criticises the way reality is given meaning. Its goal is to reveal, to unmask, to make things visible which were previously concealed. Many authors therefore use the term precisely to make resistance and opposition visible, or at least to generate a space, a discourse, in which they can become visible (Mouffe 2006; Rancière 2001; 2006; Žižek 2000). It is in this sense that I completely disagree with the suggestion that theories of the post-political would make us blind to actually existing forms of contestation.

Acknowledgements: I want to warmly thank all transitioners and climate justice activists who I got to know during the years, for sharing their thoughts, dreams, ideas, feelings, reflections, anger, hope, and especially their commitment, spirit and engagement with me. 


\section{References}

Bailey I, Hopkins R and Wilson G

2010 Somethings old, somethings new: The spatial representations and politics of change of the peak oil relocalisation movement. Geoforum 41(4):595-605.

Barnett C

2013 Varieties of 'the political'. Available online.

Baxter J and Eyles J

1997 Evaluating qualitative research in social geography: establishing 'rigour' in interview analysis. Transactions of the Institute of British Geographers 22(4):505-525.

Bettini G

2013 Climate Barbarians at the Gate? A critique of apocalyptic narratives on 'climate refugees'. Geoforum 45:63-72.

Brangwyn B and Hopkins R

2008 Transition initiatives primer: becoming a transition town, city, district, village, community or even island. Devon: Transition Network.

Chatterton $\mathrm{P}$, Featherstone $\mathrm{D}$ and Routledge $\mathrm{P}$

2013 Articulating Climate Justice in Copenhagen: Antagonism, the Commons, and Solidarity. Antipode 45(3):602-620.

CJA-Leaflet

2009 System change! Not climate change. Take action in Copenhagen!

ClimateCollective

2009 Action Guide to COP15.

Dikeç M

2005 Space, politics, and the political. Environment and Planning D: Society and Space 23:171-188.

2012 Space as a mode of political thinking. Geoforum 43:669-676.

Esterberg KG

2002 Qualitative Methods in Social Research. London: Mc Graw Hill.

Featherstone D

2013 The Contested Politics of Climate Change and the Crisis of Neo-liberalism. ACME. An International E-Journal for Critical Geographies 12(1):44-64.

Featherstone D and Benedikt $\mathrm{K}$

2012 Introduction: Space, contestation and the political. Geoforum 43(4):663-668.

Goeminne G

2012 Lost in translation: climate denial and the return of the political. Global Environmental Politics $12(2): 1-8$ 
Hopkins R

2008a "The Rocky Road to a Real Transition": A Review. Available online.

Hopkins R

2008b The Transition Handbook. From oil dependency to local resilience. Devon: Green Books.

Howarth D, Norval AJ and Stavrakakis Y

2000 Discourse theory and political analysis. Identities, hegemonies and social change. Manchester: University Press.

Kenis A

2016 Ecological citizenship and democracy: Communitarian versus agonistic perspectives

Environmental Politics 25(6): 949-970.

Kenis $\mathrm{A}$ and Lievens $\mathrm{M}$

2014 Searching for 'the political' in environmental politics. Environmental Politics 23(4): 531-548.

2015 The Limits of the Green Economy. From re-inventing capitalism to repoliticising the present. London: Routledge.

2016 Greening the economy or economizing the green project? When environmental concerns are turned into a means to save the market. Review of Radical Political Economics 48(2): 217234.

Kenis $A$ and Mathijs $E$

2014a (De)politicising the local: The case of the Transition Towns movement

in Flanders (Belgium). Journal of Rural Studies 34: 172-183.

2014b Climate change and post-politics: Repoliticising the present by imagining the future? Geoforum 52: 148-156.

Klein $\mathrm{N}$

2002 Fences and windows. London: Flamingo.

Laclau E

1996 Emancipation(s). London: Verso.

Laclau E and Mouffe C

2001 Hegemony and Socialist Strategy : towards a Radical Democratic Politics. London: Verso.

Larner W

2014 The Limits of Post-Politics: Rethinking Radical Social Enterprise. In The Post-Political and its Discontents. Spaces of Depoliticisation, Spectres of Radical Politics. J. Wilson and E. Swyngedouw, eds. Pp. 189-207. Edinburgh: Edinburgh University Press.

Lievens $\mathrm{M}$

2010 Carl Schmitt's Two Concepts of Humanity. Philosophy and Social Criticism 36(8):917-934. 
2013 Carl Schmitt's Metapolitics. Constellations 20(1):121-137.

\section{MacGregor S}

2014 Only Resist: Feminist Ecological Citizenship and the Post-politics of Climate Change. Hypatia 29(3):617-633.

Machin A

2013 Negotiating climate change. Radical democracy and the illusion of consensus. London: Zed Books.

Maeseele P

2015 Beyond the post-political Zeitgeist. In A Handbook of Environment and Communication. A Hansen and R Cox, eds. New York: Routledge.

Marchart O

2007 Post-Foundational Political Thought: Political Difference in Nancy, Lefort, Badiou and Laclau. Edinburgh: Edinburgh University Press.

Mason $\mathrm{K}$ and Whitehead $\mathrm{M}$

2012 Transition Urbanism and the Contested Politics of Ethical Place Making. Antipode 44(2):493516.

McCarthy J

2013 We Have Never been "Postpolitical". Capitalism Nature Socialism 24(1):19-25.

Mouffe C

2000 The Democratic Paradox. London: Verso.

2002 Politics and Passions. The Stakes of Democracy. London: CSD Perspectives.

2006 On the Political. London: Routledge.

Mouffe $\mathrm{C}$ and Laclau $\mathrm{E}$

2001 Hegemony and socialist strategy: towards a radical democratic politics. London: Verso.

Müller T

2008 The movement is dead, long live the movement! Turbulence 4:48-54.

Neal S

2013 Transition culture: Politics, localities and ruralities. Journal of Rural Studies 32:60-69.

North P

2010 Eco-Localisation as a progressive response to peak oil and climate change. A sympathetic critique. Geoforum 41(4):585-594.

2011 The politics of climate activism in the UK: a social movement analysis. Environment and Planning D 43(7):1581-1598.

OECD

2011 Towards Green Growth. 
Pepermans $\mathrm{Y}$ and Maeseele $\mathrm{P}$

2016 The politicization of climate change: problem or solution? . Wiley Interdisciplinary Reviews: Climate Change 7(4):478-485.

Rancière J

2006 Hatred of democracy. London: Verso.

2001 Ten Theses on Politics. Available online.

Robert M, Schetter C and Prinz J

2012 Spatial contestation? The theological foundations of Carl Schmitt's spatial thought. Geoforum 43(4):687-696.

Routledge P

2003 Convergence space: process geographies of grassroots globalization networks, New Series. Transactions of the Institute of British Geographers 28:333-349.

Swyngedouw E

2007 Impossible "Sustainability" and the Postpolitical Condition. In The Sustainable Development Paradox. R Krueger and D Gibbs, eds. London: The Guilford Press.

2010 Apocalypse Forever? Theory, Culture \& Society 27(2-3):213-232.

2013 The Non-political Politics of Climate Change. ACME: An International E-Journal of Critical Geographies 12(1):1-8.

UNEP

2011 Towards a Green Economy: Pathways to Sustainable Development and Poverty Eradication.

Urry J

2011 Climate Change and Society. Cambridge: Polity Press.

Valentine G

2005 Tell me about . . . : using interviews as a research methodology. In Methods in Human Geography. R. Flowerdew and D. Martin, eds. Edinburgh: Pearson Education Limited.

Žižek S

2000 The Ticklish Subject. The Absent Centre of Political Ontology. London: Verso. 